\title{
The Association Between Knowledge and Preventive Behavior of Cervical Cancer Among Woman Employees in The Companies in Jakarta
}

\author{
Febri Hardiyanti ${ }^{1}$, Johan Harlan ${ }^{2}$, Ema Hermawati ${ }^{1}$ \\ ${ }^{1}$ Environmental Health Department, Faculty of Public Health, University of Indonesia, West Java, Indonesia \\ ${ }^{2}$ Midwifery Department, Gunadarma University, West Java, Indonesia
}

\section{ARTICLE INFO}

Received : 28 July 2019

Reviewed : 15 August 2019

Accepted : 15 January 2020

\section{Keywords:}

cervical cancer, knowledge, preventive behavior

\begin{abstract}
Background: Cervical cancer is the second most frequent malignant tumor among women in the world and the most common type of cancer found among women in developing countries, including Indonesia. It has been predicted that the number of people who have this cancer will increase in the future due to lifestyle changes. The study aims to determine the association between the knowledge and the preventive behavior of cervical cancer among woman employees in the companies in Jakarta.
\end{abstract}

\begin{abstract}
Methods: This research is a quantitative analytical study, with a cross-sectional design. The purposive sampling method was performed to choose the respondents, who are the employees of 3 companies in Jakarta. One hundred married women were selected as the research respondents, namely $32 \mathrm{ET}$ employees, $37 \mathrm{BTI}$ employees, and $31 \mathrm{AT}$ employees. The data were collected using the questionnaires on the knowledge of cervical cancer as an independent variable and the preventive behavior of cervical cancer as a dependent variable. The data collection was conducted from March to April. The statistical trial analysis was performed with the Chi-Square test.
\end{abstract}

Results: From the results of the research, it was found that $74 \%$ of the employees have enough preventive behavior of cervical cancer. A total of $73 \%$ of employees have good cervical cancer knowledge. The Chi-square test between the knowledge and preventive behavior of cervical cancer obtains $P=.043 ;$ OR $3.68,95 \% \mathrm{Cl} 1.005-13.474$. It means there is an association between the knowledge and the preventive behavior of cervical cancer among woman employees in the companies in Jakarta.

Conclusions: Good cervical cancer knowledge is significantly associated with good cervical cancer preventive behavior among woman employees in the companies in Jakarta.
*Corresponding author:

Febri Hardiyanti

Faculty of Public Health, University of

Indonesia, West Java, Indonesia

febrihardiw@gmail.com among women in developing countries, including Indonesia [1].

In Indonesia, cervical cancer has increased by $17.2 \%$ $(32,469)$ [3]. To reduce the incidence rate of cervical cancer, cervical cancer prevention requires a multipurpose approach involving primary, secondary, and tertiary preventions [4]. Screening strategies should consider the benefits and risks of screening to avoid unnecessary discovery and treatment of transient infections of human papillomavirus (HPV) [5]. Risk factors for the incidence of cervical cancer include the age of first war, the multiple age of the first pregnancy, multiparity, prolonged use of oral contraceptives, history of sexually transmitted infections, smoking, low fruit and vegetable diets, and lack of routine cytologic screening or previous abnormal operation. 
Preventive strategies should start from a young age to the end of the reproductive age of all social groups, including woman employees. In 2016 in Indonesia, the number of the working-age population (15 years and above) is 189 million. The percentage of working-age women increased by $50.6 \%$ from 1996 [6]. The development of the female labor force participation rate in Jakarta is increasing year by year. From 2017 to early 2018, the increase in female labor force participation reached $10 \%$ [7]. With the modernization and emancipation of women, women of productive age work in large cities.

The 2016 international conference with the theme "Global Cancer: Occurrence, Causes, and Avenues to Prevention" revealed that half of all cancers could be avoided if current knowledge was adequately translated into preventive interventions [8]. Knowledge of risk factors also increases the number of screening participation in cervical cancer. In China, the knowledge of cervical cancer screening among women was found to be poor [9]. In another country, the knowledge and awareness of HPV infection and cervical cancer among Tunisian women were found to be moderate [10]. Indian women had poor knowledge of cervical cancer screening [11].

In Indonesia, despite the large woman population, there was no previous study of cervical cancer knowledge especially on woman employees in the companies in Jakarta. Higher education stigma may affect the knowledge and preventive behavior of cervical cancer. On the other side, the government needs to know the knowledge of the population. It's urgent that a targeted health promotion intervention, especially targeting older women, focus on improving their cervical cancer knowledge and encouraging them to communicate with health care providers. The health promotion intervention targeting health care providers is also important to improve their knowledge of cervical cancer and provide the best advice to women [11]. Therefore, through this study, we can analyze the appropriate methods and operations in increasing the knowledge to improve cervical cancer preventive behavior.

The study aims to determine the association between the knowledge and the preventive behavior of cervical cancer among woman employees in the companies in Jakarta.

\section{METHODS}

\section{Participant}

This research is a quantitative analytical study, with a cross-sectional design. The population in this study consists of all employees of the ET, BTI, and AT companies.
The data collection was conducted from March to April. The samples was determined using the Lemeshow's technique [12], with a level of significance of $95 \%$ and an absolute precision of 0.1 . The substantial sample calculation results reach 96.04, rounded into 100 samples. The inclusive criterion of this research was 100 married women who work for the three companies. The purposive sampling method was used to select the sample. One hundred married women were selected as the research respondents, namely 32 ET employees, 37 BTI employees, and 31 AT employees.

The research was conducted using the questionnaires, which of the cervical cancer knowledge and preventive behavior. The questionnaire of cervical cancer knowledge consists of questions about risk factors, symptoms, and prevention of cervical cancer. The knowledge of the respondent is categorized good if he/she can answer correctly by $\geq 20$ out of 30 questions asked; it is categorized enough if the respondent can answer $<20$ questions correctly from the 30 questions asked.

Cervical cancer preventive behavior is the behavior of respondents related to the ways of preventing cervical cancer. There are 9 questions regarding cervical cancer preventive behavior with the highest score of 11 . It is categorized good if the respondent gets a score of $\geq 8$ and enough if his/her score is $<8$. The respondents get higher scores if they have ever gotten an HPV vaccine, are not active nor passive smokers, are not using longterm hormonal contraceptives, got married over the age of 20 years, regularly use condoms during sexual intercourse, consume fruits and vegetables, have regular exercise, and have routine Pap smears.

\section{Statistical Analysis}

The data were analyzed using SPSS version 22. The univariate data analysis was performed on the data of the knowledge and preventive behavior of cervical cancer. Then, the data of the knowledge and preventive behavior of cervical cancer were processed by the bivariate using the Chi-square test with confidence interval of $95 \%$.

\section{RESULTS}

The respondents in this study were 100 married woman employees. The characteristics of the respondents are pictured in Table 1 . Thirty seven percent of them came from BTI company, 32\% from ET company, and 31\% from AT company. The majority of respondents were 20-30 years old (58\%), receiving bachelor and master degrees (56\%), getting married at the age of 21-30 (81\%), total labor and performing abortion once (43\%). 
Table 1. Respondent Research Characteristics

\begin{tabular}{lc}
\hline Characteristics & Percentage \\
\hline Age (years old) & \\
$20-30$ & $58 \%$ \\
$31-40$ & $34 \%$ \\
$41-50$ & $8 \%$ \\
Company & \\
ET & $32 \%$ \\
BTI & $37 \%$ \\
AT & $31 \%$ \\
Education & \\
High school & $14 \%$ \\
Diploma & $30 \%$ \\
Bachelor and graduate & $56 \%$ \\
Age of marriage (years) & \\
$\leq 20$ & $11 \%$ \\
$21-30$ & $81 \%$ \\
$>31$ & $8 \%$ \\
Total labor and abortus & \\
0 & $21 \%$ \\
1 & $43 \%$ \\
2 & $32 \%$ \\
$>2$ & $4 \%$ \\
\hline
\end{tabular}

Table 2. Overview of cervical cancer prevention

\begin{tabular}{|c|c|}
\hline Behavior & Percentage \\
\hline \multicolumn{2}{|l|}{ Getting HPV vaccine: } \\
\hline Already & $3 \%$ \\
\hline Not Yet & $97 \%$ \\
\hline \multicolumn{2}{|l|}{ Smoking: } \\
\hline Active Smoker & $2 \%$ \\
\hline Passive smoker & $40 \%$ \\
\hline Not active or passive smoker & $58 \%$ \\
\hline \multicolumn{2}{|l|}{ Use of Hormonal contraceptives: } \\
\hline Yes & $8 \%$ \\
\hline No & $92 \%$ \\
\hline \multicolumn{2}{|l|}{ Age of Marriage: } \\
\hline$\leq 20$ years & $11 \%$ \\
\hline$>21$ years old & $89 \%$ \\
\hline \multicolumn{2}{|l|}{ Number of childbirth and abortion: } \\
\hline 0 times & $21 \%$ \\
\hline 1-2 Times & $75 \%$ \\
\hline$>2$ times & $4 \%$ \\
\hline \multicolumn{2}{|l|}{$\begin{array}{l}\text { Routine use of condoms during } \\
\text { sexual intercourse: }\end{array}$} \\
\hline Yes & $12 \%$ \\
\hline No & $88 \%$ \\
\hline \multicolumn{2}{|l|}{ Types of foods consumed: } \\
\hline Fast food & $18 \%$ \\
\hline Fruits and vegetables & $82 \%$ \\
\hline \multicolumn{2}{|l|}{ Exercising routines: } \\
\hline Yes & $27 \%$ \\
\hline No & $73 \%$ \\
\hline \multicolumn{2}{|l|}{ Routine pap smear: } \\
\hline Yes & $9 \%$ \\
\hline No & $91 \%$ \\
\hline
\end{tabular}

The preventive behavior of cervical cancer conducted by respondents is shown in Table 2 . The majority of respondents or $97 \%$ have not received the HPV vaccine.
$58 \%$ of the respondents not active nor passive smokers. The percentage of the respondents who have never used hormonal contraceptives is $92 \%$. Most respondents got married at the age of more than 21 years by $89 \%$. About $75 \%$ of the respondents have experienced $1-2$ times of giving a birth and abortion. Eighty eight percent of them did not use condoms during sexual intercourse. Eighty two percent of them consumed fruits and vegetables more frequently. The number of respondents who have a regular exercise is $27 \%$. Nine percent of the respondents expressed to have regular Pap smears.

Cervical cancer preventive behavior is the behavior of the respondents related to the ways of preventing cervical cancer. There are 9 questions regarding cervical cancer preventive behavior with the highest score of 11 . The preventive behavior is categorized good if the respondent gets a score of $\geq 8$ and enough if the score is $<8$. The respondents get higher scores if they've ever gotten an HPV vaccine, are not an active and passive smoker, are not using long-term hormonal contraceptives, got married over the age of 20 years, regularly use of condoms during sexual intercourse, consume fruits and vegetables, have regular exercise, and have routine pap smears.

Based on the results of the univariate test of cervical cancer which is presented in Table 3, it was found that the majority of respondents or $74 \%$ have enough preventive behavior of cervical cancer and $26 \%$ have good preventive behavior.

Table 3. The level of cervical cancer prevention

\begin{tabular}{lc}
\hline Cervical Cancer prevention behaviour & Percentage \\
\hline Good & $26 \%$ \\
Enough & $74 \%$ \\
Total & $100 \%$ \\
\hline
\end{tabular}

The results of the univariate test of cervical cancer knowledge are tabulated in Table 4. The majority of respondents' knowledge levels of cervical cancer are categorized as good (73\%).

Table 4. Levels of cervical cancer knowledge

\begin{tabular}{lc}
\hline Cervical cancer knowledge & Percentage \\
\hline Good & $73 \%$ \\
Enough & $27 \%$ \\
Total & $100 \%$ \\
\hline
\end{tabular}

The analytical bivariate regarding the association between the knowledge and the preventive behavior of cervical cancer can be seen in Table 5. Twenty three respondents have good knowledge and preventive behavior of cervical cancer. Fifty respondents have good knowledge with enough preventive behavior of cervical cancer. 
Three respondents have enough knowledge with good cervical cancer preventive behavior. A total of 24 respondents have enough cervical cancer knowledge and enough preventive behavior of cervical cancer.

From the results of data processing using the Chisquare test between the cervical cancer knowledge and preventive behavior, it was obtained the $P=.043$; OR $3.68,95 \% \mathrm{Cl} 1.005-13.474$. It means that there is a meaningful association between the cervical cancer knowledge and preventive behavior.

Table 5. Association cervical cancer knowledge with cervical cancer prevention behavior

\begin{tabular}{lrrrrr}
\hline Knowledge of & \multicolumn{2}{c}{ Behavior } & Total & $P$ & OR \\
\cline { 2 - 3 } Cervical Cancer & Good & Enough & & & \\
\hline Good & 23 & 50 & 73 & & 3.680 \\
Enough & 3 & 24 & 27 & 0.043 & $(1.005-$ \\
Total & 26 & 74 & 100 & & $13.474)$ \\
\hline
\end{tabular}

Based on the test result statistics, the $P=.043$, which means there is a meaningful association between the knowledge and the preventive behavior of cervical cancer. Women with good knowledge are 3,680 times better to have good cervical cancer preventive behavior.

Based on the results of the study, it is revealed that there is an association between the knowledge and preventive behavior of cervical cancer; therefore, it is necessary to improve the strategy to increase the knowledge of cervical cancer in all communities. Cooperation by all sectors, ranging from corporate institutions, government sectors related to health promotion, and non-profit institutions is required, which can contribute to increasing the knowledge of cervical cancer and can eventually improve the preventive behavior and decrease incidence rate of cervical cancer. Also, we can utilize the time media to raise awareness and behavioral health with cancer among women.

\section{DISCUSSION}

The assessment indicators of cervical cancer preventive behaviors in this study include conducting HPV vaccination, delaying sexual activity, loyal to spouse, use of contraceptive barrier (condoms, diaphragm), implementing self-hygiene patterns, not smoking, restricted use of hormonal contraceptives and consumption of nutrients rich in antioxidants, and applying a healthy lifestyle. The use of HPV vaccination is the most effective method to prevent cervical cancer. It is an active behavior in the prevention of cervical cancer. The vaccination that was discovered by lan Fauzer began circulating in the world in 2006 and was listed in the Indonesian Medicine list in 2009. At that time, the
Australian order had been providing HPV vaccination for free since 2007 for girls aged 12-14 years, and it has been successful in administering HPV vaccination on 118,000 women in the country since 2007 [13]. In Indonesia, HPV vaccination is still rare. In this study, only 3 out of 100 respondents were using HPV vaccine.

In this study, $2 \%$ of the respondents were active smokers and $40 \%$ passive smokers. Tobacco endangers health, the treasury, and the spirit of Indonesia. Each year, more than 225,700 of Indonesian people are killed by tobacco-induced illnesses. Although fewer women smoke in Indonesia than the average in the developing world, there are still more than 1,956,700 (2.1\%) women who smoke every day, causing a threat of ongoing and terrible public health [14].

In this study, among 100 respondents, $8 \%$ of them have been using hormonal contraceptives for more than five years. Limiting the use of hormonal contraceptives is one of the active behavior in the prevention of cervical cancer. However, hormonal contraceptives are still the main choice of Indonesian women. A total of $54.85 \%$ of reproductive-age women are using contraception. The three most popular contraceptive methods are injections (40.88\%), pills $(28.48 \%)$ and IUD (13.84\%). Hormonal contraceptives can increase the relative risk of cervical cancer of 1.53 times if used for more than 5 years [15]. The case-control study conducted by Tira showed from 58 patients with cervical cancer, 37 people (63.8\%) had used hormonal pills for more than five years [16].

Delaying sexual activity is one of the preventive behavior of cervical cancer although getting married at a young age is still a culture of Indonesian society. Indonesians are included in the highest percentage of young children up to $37 \%$ in the world [17]. The average age of the respondents who were married in this study was 25 years. Seeing the marriage age of most respondents over 20 years, it is concluded that the respondents have a good behavior in delaying sexual activities as a preventive behavior for cervical cancer.

National Population and Family Planning Board Advocacy Program of having two children has a longterm implication for suppressing the incidence of cervical cancer. Women who have been pregnant six times or more have the risk of developing cervical cancer 1.9 times greater than those with 1-5 times of pregnancy [18]. Women who did abortion once have a relative risk of 2.3 to suffer from cervical cancer than those who had never. In this study, $4 \%$ of women have experienced labor and abortion more than two times. A total of $75 \%$ had a labor and abortion 1-2 times. The respondents of this research have relatively good behavior in minimizing the history of labor and abortion as a preventive behavior for cervical cancer.

A condom is an effective barrier contraceptive device in preventing cervical cancer. The results of the study of 82 people conducted by Moore" indicate that women 
who claim their spouses always use condoms during sexual intercourse are $70 \%$ less likely to be exposed to HPV compared to those whose partners use condoms (not up to $5 \%$ of the whole number of sex intercourses) very rarely [19]. In this study, only $12 \%$ of the respondents routinely used condoms. This suggests that they had less relative behavior in the use of condoms routinely when having sexual intercourse as a preventive behavior of cervical cancer.

A healthy lifestyle is one of the preventive measures of cervical cancer. Another measure is by consuming vegetables and fruit regularly, and exercising. In this study, the majority of the respondents or $88 \%$ had consumed vegetables and fruit, but only 27 had exercised routinely.

In developing countries, the Pap smear test is still the main measure in preventing cervical cancer because of the level of consciousness and ability of people in developing countries to vaccinate HPV. However, health screening is rarely done by Indonesian women. This study showed that $91 \%$ of the respondents never performed a Pap smear. It is identified that women who have good knowledge four times more often have a Pap smear test compared to those who have less knowledge.

Knowledge of the prevention of cervical cancer in woman employees in Jakarta can be categorized as good and they have enough behavior to prevent cervical cancer. In general, $73 \%$ of the woman employees in the companies in Jakarta have good knowledge of cervical cancer. The knowledge is due to differences in educational background, occupation, age, information sources, socio-culture, economy, and environment. The knowledge also affects individual health behavior.

This research can be used as a basis on the knowledge of cervical cancer among women with higher education, especially in Jakarta, whether the assumption of higher education is in line with good cervical cancer prevention behavior. However, this research has a limitation, which is the questions about behavior not being studied deeply with open questions. For further studies, it is expected to add qualitative research with open questions that can represent the behavior of the respondents more deeply.

\section{CONCLUSIONS}

Woman employees in the companies in Jakarta have good knowledge and enough preventive behavior of cervical cancer. Therefore, there is an association between the knowledge and prevention of cervical cancer of woman employees in the companies in Jakarta.

\section{DECLARATIONS}

\section{Competing of Interest}

The authors declare no competing interests.

\section{Acknowledgement}

The Authors would like to thank all of the companies and employees who have been very friendly and cooperative during research data collection. We also express our gratitude to the reviewers, the technical editor, and the language editor.

\section{REFERENCES}

1. Bray F, Ferlay J, Soerjomataram I, Siegel RL, Torre LA, Jemal A. Global cancer statistics 2018: GLOBOCAN estimates of incidence and mortality worldwide for 36 cancers in 185 countries. CA Cancer J Clin. 2018;68(6):394-424.

2. World Health Organization. Global Health Observatory. Geneva: World Health Organization; 2018. Cited July 21, 2019. Available from who.int/gho/database/ en/.

3. International Agency for Research on Cancer, GLOBOCAN database [Internet]. 2018. [cited 10 July 2019]. Available from: http: //globocan.iarc.fr/ factsheet.asp

4. Aggarwal P. Cervical cancer: Can it be prevented?. World J Clin Oncol. 2014;5(4):775-80.

5. Mc Graw SL, Ferrante JM. Update on prevention and screening of cervical cancer. World J Clin Oncol. 2014;5(4):744-52.

6. International Labour Organization. Indonesia Jobs Outlook 2017: Harnessing Technology for Growth and Job Creation. Jakarta. 2017.

7. Badan Pusat Statistik. Employment condition of DKI Jakarta August 2018. Jakarta; 2018;(53): 1-9.

8. WHO. Global Cancer: Occurrence, Causes, and Avenues to Prevention. 2016 [cited 2019 Sep 10]. Available from: http://www.iarc-conference2016.com

9. Di J, Rutherford S, Wu J, Song B, Ma L, Chen J, et al. Knowledge of cervical cancer screening among women across different socio-economic regions of China. PLoS One. 2015;10(12):e0144819.

10. Gamaoun R. Awareness and knowledge about cervical cancer prevention methods among Tunisian women. Journal Prevention Medical Hygiene. 2018;59(1):E30-5.

11. Thovarayi S, Noronha JA, Nayak S. Knowledge of cervical cancer screening among rural Indian women : A cross sectional study. Journal of Nursing and Health Science. 2014;3(3):51-5. 
12. Lemeshow, Stanley, Hosmer, David W, Klar, Janelle, Lwanga, Stephen Kaggwa \& World Health Organization. Adequacy of Sample Size in Health Studies. Chichester: Wiley: 1990.

13. NSW Government. Human Papillomavirus Vaccine [Internet]. 2012. [cited 23 Juli 2019]. Available from https://www.cancer.nsw.gov.au

14. Tobacco Atlas. Fact Sheet Tobacco in Indonesia [Internet]. 2015. [cited 23 Juli 2019]. Available from https://tobaccoatlas.org

15. Indonesian Society of Oncology. Management guidelines for cancer. Faculty of Medicine Universitas Indonesia. Jakarta. 2010.

16. Tira D. A risk of total marriage, abortus history, and the use of hormonal contraceptives against the incidence of cervical cancer at the Makassar Pelamonia Hospital in 2006-2007. MKM. 2008; 3(1):20-28.
17. Arimurti I, Nurmala I. Analysis of women's knowledge of conduct of early childhood marriage in Wonosari subdistrict Bondowoso district. The Indonesian Journal of Public Health. 2017;12(2):249-62.

18. Sogukpinar N. Assessment of cervical cancer risk in women between 15 and 49 years of age: Case of Izmir. Asian Pacific Cancer Prevention Journal. 2013;14:2119-25.

19. Moore D. Cervical cancer. Obstetry Gynecology. 2006;107(5):1152-61.

\section{Appendix}

Cervical cancer prevention questionnaire

\section{"Hubungan Pengetahuan Kanker Serviks dengan Perilaku Pencegahan Kanker Serviks pada Karyawan Wanita Perusahaan di Jakarta"}

PETUNJUK PENGISIAN:

1. Kuesioner perilaku pencegahan kanker serviks memuat 10 pertanyaan. Responden diberikan waktu menjawab 10 menit. Responden dapat menjawab pernyataan dengan sejujurnya karena jawaban responden merupakan sumber data penelitian yang akan dijamin kerahasaiaannya.

2. Beri checklist $(\mathrm{V})$ pada pernyataan yang sesuai dengan yang Saudara alami

\section{KUESIONER PERILAKU PENCEGAHAN KANKER SERVIKS}

\section{Perilaku Pencegahan Kanker Serviks}

1. Apakah Saudara pernah mendapatkan suntikan HPV?

$\square$ Sudah Jika sudah, berapa kali Saudara mendapatkan suntikan HPV? ....... kali

Saat Saudara berusia ....... tahun

Belum

2. Saudara merupakan ........

Perokok Aktif Sejak usia berapa Saudara mulai merokok? ....... tahun

Berapa batang per hari? ....... batang/hari

Perokok Pasif (menghirup asap rokok dari lingkungan kerja, lingkungan rumah)

Bukan Perokok Aktif maupun Pasif

3. Apakah Saudara pernah atau sedang memakai alat kontrasepsi hormonal?

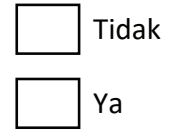

Jenis alat kontrasepsi yang digunakan? (Sebutkan alat kontrasepsi yang pernah Saudara gunakan dan sedang Saudara gunakan saat ini, serta lama pemakaiannya)

\begin{tabular}{|c|c|}
\hline Pil & Lama penggunaan ....... tahun \\
\hline Suntik & Lama penggunaan ....... tahun \\
\hline Implant/susuk & Lama penggunaan ....... tahun \\
\hline
\end{tabular}


4. Berapakah usia Saudara saat menikah? tahun

5. Berapa kali jumlah persalinan yang Saudara alami? kali persalinan

6. Apakah setiap kali melakukan hubungan seksual, Saudara mewajibkan pasangan menggunakan kondom?<smiles>[Te][C]1CCC1</smiles>

Tidak; alasan

7. Jenis makanan apa yang lebih sering Saudara konsumsi?

$\square$ Makanan cepat saji

$\square$ Buah dan sayur

8. Apakah Saudara rutin melakukan olahraga?
$\square$ Ya
Berapa kali Saudara melakukannya?
$\square$ Tidak

9. Apakah Saudara pernah melakukan Pap Smear?
$\square$ Ya
Tiap berapa lama Saudara melakukan Pap Smear? .......
Tidak

\section{KUESIONER PENGETAHUAN KANKER SERVIKS}

\section{PETUNJUK PENGISIAN:}

1. Kuesioner pengetahuan kanker serviks secara keseluruhan memuat 30 pertanyaan. Kuesioner terbagi atas 3 sub bagian, yaitu pengetahuan faktor risiko kanker serviks (10 pertanyaan), pengetahuan gejala kanker serviks (10 pertanyaan) dan pengetahuan pencegahan kanker serviks (10 pertanyaan). Responden diberikan waktu menjawab pertanyaan selama 30 menit.

2. Beri checklist $(\mathrm{V})$ pada pernyataan yang sesuai dengan jawaban Anda anggap benar.

\section{Pengetahuan Faktor Risiko Kanker Serviks}

\begin{tabular}{|c|c|c|c|}
\hline \multirow{2}{*}{ No. } & \multirow{2}{*}{ Pertanyaan } & \multicolumn{2}{|c|}{ Jawaban } \\
\hline & & Benar & Salah \\
\hline 11 & $\begin{array}{l}\text { Kanker leher rahim (serviks) hanya akan terjadi pada seorang wanita } \\
\text { jika ia telah berusia } 60 \text { tahun. }\end{array}$ & & \\
\hline 12 & $\begin{array}{l}\text { Seorang wanita yang terlalu dini melakukan hubungan seksual } \\
\text { mendapat peluang lebih kecil terkena kanker serviks. }\end{array}$ & & \\
\hline 13 & $\begin{array}{l}\text { Seorang wanita yang keluarganya mengalami kanker, } \\
\text { mendapat peluang lebih besar terkena kanker serviks. }\end{array}$ & & \\
\hline 14 & $\begin{array}{l}\text { Lelaki yang melakukan hubungan seksual berganti-ganti pasangan } \\
\text { tidak bisa menjadi penyebab terjadinya kanker serviks pada pasangannya. }\end{array}$ & & \\
\hline 15 & $\begin{array}{l}\text { Lelaki yang belum sirkumsisi (khitan) tidak bisa membawa virus HPV } \\
\text { (virus penyebab kanker serviks) pada alat kelaminnya. }\end{array}$ & & \\
\hline 16 & $\begin{array}{l}\text { Wanita yang sering berganti pasangan seksual } \\
\text { berisiko besar mengalami kanker serviks }\end{array}$ & & \\
\hline 17 & $\begin{array}{l}\text { Penderita HIV-AIDS mempunyai peluang lebih besar } \\
\text { untuk menderita kanker serviks. }\end{array}$ & & \\
\hline 18 & Pemakaian KB suntik dapat mengurangi risiko kanker serviks & & \\
\hline 19 & Kanker serviks tidak dapat terjadi bila wanita memakai pembalut herbal. & & \\
\hline 20 & Wanita perokok lebih mudah mengalami kanker serviks & & \\
\hline
\end{tabular}




\section{Kuesioner Gejala Kanker Serviks}

\begin{tabular}{lll}
\hline No. & \multicolumn{1}{c}{ Pertanyaan } & Jawaban \\
\cline { 2 - 3 } 21 & Nyeri pada payudara menjadi tanda awal terjadinya kanker serviks. & Salah \\
22 & Nyeri perut saat menjelang menstruasi merupakan gejala kanker serviks. \\
23 & $\begin{array}{l}\text { Sering pusing, mata berkunang dan nafsu makan menurun menjadi tanda } \\
\text { awal terjadinya kanker serviks. }\end{array}$ \\
24 & $\begin{array}{l}\text { Keputihan yang banyak dan terus menerus disertai gatal dan bau } \\
\text { merupakan tanda awal terjadinya kanker serviks. }\end{array}$ \\
25 & $\begin{array}{l}\text { Keputihan yang banyak, bening dan muncul sesaat sebelum menstruasi } \\
\text { bisa menjadi tanda awal kanker serviks. }\end{array}$ \\
26 & $\begin{array}{l}\text { Bercak darah setelah melakukan hubungan seksual merupakan gejala } \\
\text { kanker serviks. }\end{array}$ \\
27 & $\begin{array}{l}\text { Timbulnya perdarahan yang banyak dan terus menerus diluar jadwal } \\
\text { menstruasi merupakan gejala kanker serviks. }\end{array}$ \\
28 & $\begin{array}{l}\text { Timbul bercak darah setelah pemakaian KB suntik bukan merupakan gejala } \\
\text { kanker serviks. } \\
29\end{array}$ \\
$\begin{array}{l}\text { Darah menstruasi yang tidak keluar saat penggunaan KB suntik } 3 \text { bulan } \\
\text { merupakan gejala kanker serviks }\end{array}$ \\
Timbul bercak darah setelah pemakaian KB spiral merupakan gejala kanker \\
serviks.
\end{tabular}

\section{Kuesioner Pencegahan Kanker Serviks}

\begin{tabular}{lll}
\hline No. & \multicolumn{1}{c}{ Pertanyaan } & Jawaban \\
\cline { 2 - 3 } 31 & Kanker serviks bisa dicegah dengan melalui pemberian vaksinasi hpv & Salah \\
32 & $\begin{array}{l}\text { Pemberian vaksin HPV hanya efektif mencegah kanker serviks yang } \\
\text { diberikan kepada wanita yang belum pernah melakukan hubungan seksual. }\end{array}$ \\
33 & Pemberian vaksin HPV bisa diberikan kepada wanita usia 9 tahun \\
34 & $\begin{array}{l}\text { Penggunaan kondom efektif mencegah penularan virus HPV (virus } \\
\text { penyebab kanker serviks). }\end{array}$ \\
35 & Menggunakan KB suntik selama 5 tahun dapat mencegah kanker serviks. \\
36 & $\begin{array}{l}\text { Membasuh genitalia (daerah kemaluan) dengan sabun dapat mencegah } \\
\text { kanker serviks. }\end{array}$ \\
38 & Merokok dapat mencegah kanker serviks. \\
39 & Mentioksidan dalam sayur dan buah dapat mengurangi risiko kanker serviks. \\
40 & Olahraga secara teratur dapat mencegah kanker serviks. \\
\hline
\end{tabular}

